\title{
IMPLEMENTATION OF INVENTORY INFORMATION SYSTEM DESIGN USING ECONOMIC ORDER QUANTITY METHOD
}

\author{
Frieyadie $^{1, *}$, Tyas Setiyorini ${ }^{2}$ \\ ${ }^{1}$ Sistem Informasi, Teknik Informatika \\ Universitas Nusa Mandiri, Jakarta, Indonesia \\ www.nusamandiri.ac.id \\ 1*) frieyadie@nusamandiri.ac.id, 2 tyas.setiyorini@gmail.com \\ *) Corresponding Author
}

\begin{abstract}
Abstrak-Permasalahan penelitian yang dihadapi adalah diantaranya biaya pemesanan barang yang selalu berubah-ubah setiap ada pemesanan. Pendataan order produk yang kurang baik dan kurang optimalnya penanganan order produk hal ini dapet merugikan perusahaan. Untuk memecahkan ketidak baikan pengangan manajemen inventory ini, maka menggunakan metode Economic Order Quantity (EOQ) dimana terbukti efektif dalam mengatasi permasalahan tersebut. Kontribusi yang dihasilkan dengan membangun sistem informasi manajemen inventory, supaya permasalahan yang dihadapi tidak terulang lagi. Tujuan dari penelitian ini supaya biaya pemesanan barang menjadi lebih stabil dan menajad lebih optimal dalam penanganan order produk.
\end{abstract}

Kata Kunci: Sistem Informasi; Economic Order Quantity (EOQ) Model Waterfall; Persediaan Barang

\begin{abstract}
The research problems faced are among others the cost of ordering goods which always changes every time there is an order. Poor product order data collection and less than optimal handling of product orders can harm the company. To solve the problem of controlling inventory management, the Economic Order Quantity (EOQ) method is used, which is proven to be effective in overcoming these problems. Contribution is generated by building an inventory management information system so that the problems faced are not repeated. The purpose of this study is to make the cost of ordering goods more stable and more optimal in handling product orders.
\end{abstract}

Keywords: Information Systems; Economic Order Quantity (EOQ) Waterfall Model; Inventory

\section{INTRODUCTION}

PT. MSJ is a company engaged in manufacturing. Where in the process of ordering raw materials, incoming or outgoing goods still use a manual process, namely by using paper to record them. Likewise with the stock items still using paper. Of course, this can create big risks that will occur. Based on observations at PT. MSJ has several obstacles, namely difficulties in finding data on a raw material stock (Ramdhany \& Fitriasih, 2019) (Humaeni, Muanas, \& Sudradjat, 2019), data processing goods, supplier data, and raw material purchase data. In the process of making reports, the company still takes a long time to prepare reports on raw material stock, incoming goods, and outgoing goods that still use paper records which at any time can be lost and damaged by rain and dirty in uncertain conditions.

The current purchasing and inventory processes are deemed not going well and efficiently, where all processes are still running manually (Cahyana, Yuwono, \& Asmoro, 2012)(Pudjiarti,
Puspitasari, \& Septyawati, 2019)(Atikah, 2017), do not have good control, and do not have good data collection (Apriani, Aisyah, \& Anggraini, 2019). As for some of the problems faced, including the cost of ordering goods which always changes every time there is an order (Tarsono \& Khotimah, 2018). This ordering cost is also influenced by the type of goods, the origin of the purchase of the goods, the amount of stock. The process of making documents that still use paper documents. Frequent document loss (Fatmawati \& Munajat, 2018)(Sidik, Waluyo, \& Susilawati, 2018), damage to documents, and the creation of double documents. Difficulty in searching for historical data, and difficulty in making inventory reports (Setiyanto, Nurmaesah, \& Rahayu, 2019). The existing system has not been able to provide accurate stock information.

Based on previous research using the EOQ method to reduce errors in data collection of ordered products (Mujiastuti, Meilina, \& Rully, 2018), so that the optimal ordering frequency can be found (Anwar, Mikhratunnisa, \& Cahyono, 2019). The method proposed in this study is the Economic 
Order Quantity (EOQ) method. This method can answer the problems faced by PT. MSJ, which can calculate the exact reorder point (Nasution \& Indriya, 2020). Optimally, it can calculate the reorder quantity. Based on the trend of using the
EOQ method (Figure 1) in 1 (one) year in 2020. The EOQ method still ranks as a widely used method for solving inventory management problems.

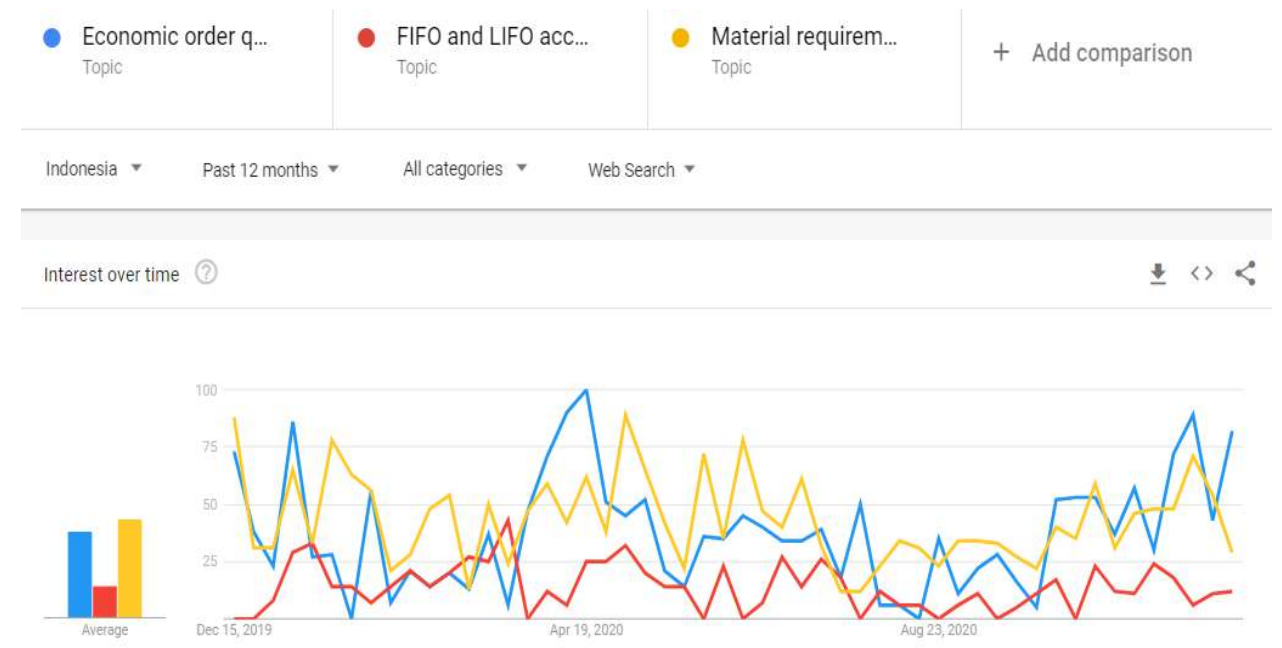

Figure 1. Trends in the Use of the EOQ Method in 2020.

This inventory information system development model adopts the waterfall model, where the flow of system development is clearer based on the phases in the waterfall model. The current research contribution refers to the application system designed and implemented at PT. MSJ.

The purpose of this research is to avoid document loss, make it easier to produce inventory reports, and be able to see accurate and correct stocks. Given the breadth of the root of the raw material inventory information system, the boundaries or coverage will be made to be analyzed. The system discussed starts from the ordering process to suppliers, warehouse stock, product categories, goods data, and releasing goods. In the process of inputting incoming goods acceptance transactions, goods releasing transactions, and printing of goods stock data reports.

\section{RESEARCH METHODS}

\section{Data collection technique}

In collecting data and information, the author researches to obtain the necessary data, by methods, including:

a. Observation

The observation process was carried out by observing directly at PT. MSJ is a system process that runs, both from the initial purchase submission until the goods being ordered are received by the warehouse so that the research process can run well and find out the needs and shortcomings.

b. Interview

The interview method is a direct question and answer process to the executive, general administration, and logistics administration to find out problems that exist in the raw material supply process.

c. Literature review

The literature study process carried out and various reference sources both internal media, journal articles related to purchasing and inventory systems.

\section{Economic Order Quantity (EOQ)}

One of the methods used to control goods in a company (Zahirah \& Arista, 2019). The existence of this EOQ method makes inventory planning better. Some things that need to be considered in the procurement of goods, namely ordering costs and storage costs. This ordering cost will continue to increase because usually, the ordering costs will continue to change, along with the number of orders for goods from suppliers. Storage costs are also a burden on the company because storage costs are also constantly changing based on the number of items stored.

EOQ has a calculation using a formula like the following: 
$E O Q=\sqrt{\frac{2 x R x S}{P}}$

From equation 1, calculating the economic order quantity, where:

R: Ordering fee (order preparation and machine storage) per order

S: Estimated use or demand per period

$P$ : Storage cost per unit per year

EOQ method can be implemented several questions can be done in the following conditions.

a. The demand for a product is constant, uniform, and known (deterministic).

b. The price per unit of product is constant.

c. Storage Cost per unit per year $(\mathrm{P})$ is Constant.

d. Order cost per order (R) is constant.

e. The time between order placed and goods received (Lead Time, $\mathrm{L}$ ) is Constant.

$\mathrm{f}$. There is no shortage of goods or "Back Orders".

\section{System Development Model}

The Waterfall model is sometimes called the classic life cycle (Pressman \& Maxim, 2015), suggests a systematic and sequential approach to software development starting with the specification of customer requirements and progressing through planning, modeling, construction, and deployment, culminating in the ongoing support of completed software.

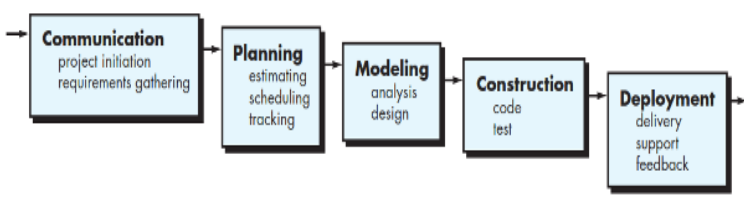

Figure 2. Waterfall Model

The following is an explanation of the Waterfall Model which is in.

a. Communication (Project Initiation \& Requirements Gathering)

Time to start technical work, the developer must meet with customers to establish communication, to understand and achieve the goals of the system to be achieved. The result of this communication is the initialization of the project, such as the need for functional characteristics of each user in the system, analyzing the problems faced, and collecting the necessary data.

b. Planning (Estimating, Scheduling, Tracking)

The 2nd (two) next step is the planning stage which describes the estimation of the technical tasks to be carried out, the risks that may occur, the resources needed to create the system, the work products to be produced, the work plans that will be carried out, and the tracing of the system work processes.

c. Modeling (Analysis \& Design)

Step 3 (three) is the stage of designing and modeling system architecture, with a focus on designing data structures, software architecture, interface displays, and program algorithms. The goal is to better understand the overall picture of what will be done.

d. Construction (Code \& Test)

Stage 4 (four) of the process of translating the design form into program code or changing the result of the design to a machine-readable language. After the coding is complete, testing is carried out on the system and also the code that has been created. The goal is to find errors that might be corrected later.

e. Deployment (Delivery, Support, Feedback)

The fifth stage (five) stages of software implementation to customers, software repair, software evaluation, and software development are based on the feedback given so that the system can continue to run and develop according to its function.

\section{RESULTS AND DISCUSSION}

The following is a discussion of system development using the Waterfall Model. Each stage of the discussion will follow the flow of the Waterfall Model stage.

\section{Communication (Project Initiation \& Requirements Gathering)}

The following is a specification of the needs of each user of the raw material inventory information system.

1. Purchasing Section

a. Can log into the system

b. Can manage product data

b. Can Manage Supplier Data

c. Can Manage Purchase Order Data

2. Warehouse Section

a. Can log into the system

b. Can Manage Incoming Items

b. Can Manage Outgoing Goods

\section{Planning (Estimating, Scheduling, Tracking)}

1. Estimating

Implementation of estimates in planning the technical tasks to be carried out, the risks that may 
occur, the resources needed to create the system, the work products to be produced

- Analyst System. In charge of carrying out system analysis to be built

- Programmer. In charge of translating the results of analysis and design that have been made in code with a programming language that suits the needs and objectives to be made
- Tester system. In charge of testing the application that is built whether it runs by the planned functional needs

2. Scheduling dan Tracking

Figure 3 is the implementation of work plans that will be carried out in the construction of an Inventory information system and also tracking work. Implementation for 16 (sixteen weeks).

\section{Inventory Information System Planner}

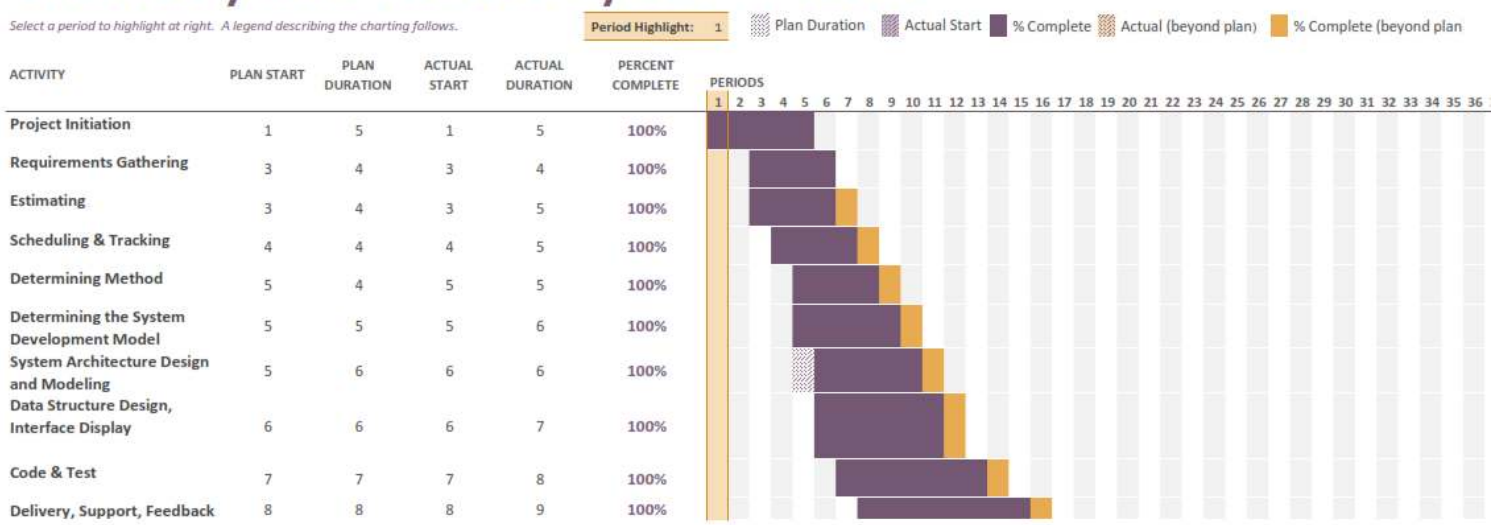

Figure 3. Inventory Information System Design

\section{Modeling (Analysis \& Design)}

Some modeling for information systems analysis using UML will be discussed by describing Use Case Diagram modeling.

a. Use Case Diagram Inventory Information System

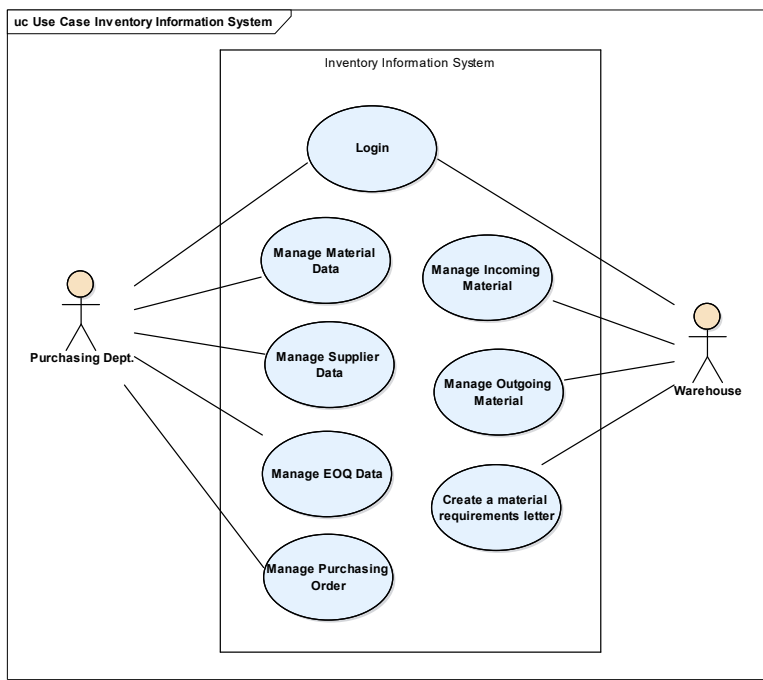

Figure 4. Use Case Diagram Inventory Information System

Table 1 explains, one of the Use Case Manage EOQ Data in Figure 4.
Table 1. Use Case Manage EOQ Data Scenarios

\begin{tabular}{lll}
\hline $\begin{array}{l}\text { Use Case } \\
\text { Name }\end{array}$ & $:$ & Manage EOQ Data \\
\hline $\begin{array}{l}\text { Use case } \\
\text { Description }\end{array}$ & $: \begin{array}{l}\text { Purchasing Dept. manage EOQ data, } \\
\text { by adding, update, deleting, and } \\
\text { printing data. }\end{array}$ \\
\hline Actors & $:$ & Purchasing Dept. \\
\hline Pre-Condition & $:$ & $\begin{array}{l}\text { The system must be connected to an } \\
\text { intranet network. Purchasing Dept. } \\
\text { must be logged in }\end{array}$ \\
\hline Post - & $:$ & $\begin{array}{l}\text { After successful login, a successful } \\
\text { message is displayed for EOQ data }\end{array}$ \\
\hline
\end{tabular}

\begin{tabular}{lll}
\hline $\begin{array}{l}\text { Main } \\
\text { Scenarios }\end{array}$ & $\begin{array}{l}\text { Serial } \\
\text { No. }\end{array}$ & \multicolumn{1}{c}{ Step } \\
\hline $\begin{array}{l}\text { Purchasing } \\
\text { Dept }\end{array}$ & 1 & Click Add to input EOQ data \\
\hline & 2 & $\begin{array}{l}\text { Click View Data to display } \\
\text { material data }\end{array}$ \\
\hline & 3 & $\begin{array}{l}\text { Click Edit Data to change material } \\
\text { data }\end{array}$ \\
\hline & 4 & $\begin{array}{l}\text { Click Clear Data to change } \\
\text { material data }\end{array}$ \\
\hline & 5 & $\begin{array}{l}\text { Permit Accessing System By } \\
\text { access rights }\end{array}$ \\
\hline Extensions & $1 \mathrm{a}$ & The added EOQ data form appears \\
\hline & 2a & The EOQ data view form appears \\
\hline 3a & The EOQ data edit form appears \\
\hline $4 \mathrm{a}$ & Clear EOQ data message appears \\
\hline $5 \mathrm{a}$ & Print EOQ data will appear \\
\hline
\end{tabular}


b. EOQ Data Browse Design

Figure 5 is an EOQ data browse plan, which

manage EOQ data, such as: add, view, edit, delete displays the overall EOQ data. Purchasing Dept. can

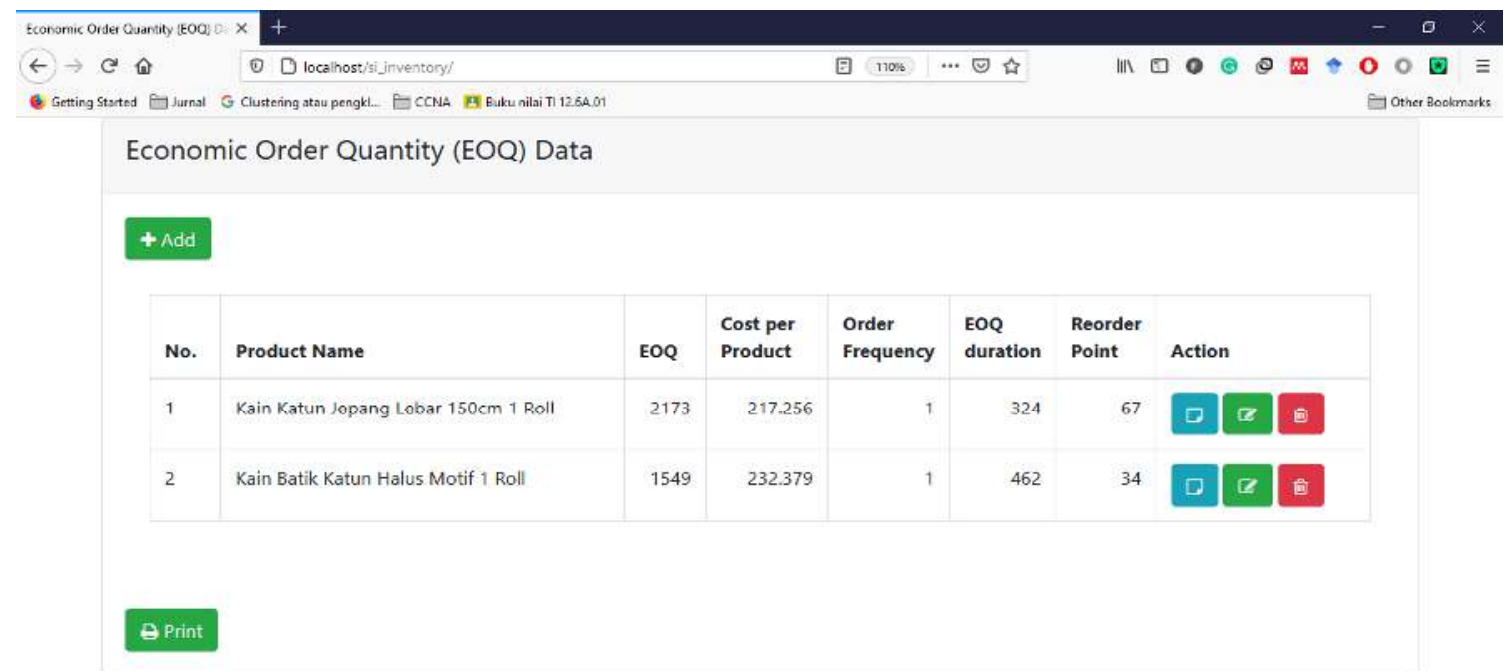

Figure 5. EOQ Data Browse Design

c. EOQ Data Input Design

Figure 6 is the form used to add EOQ data, some field items that must be inputted by the Purchasing Dept.

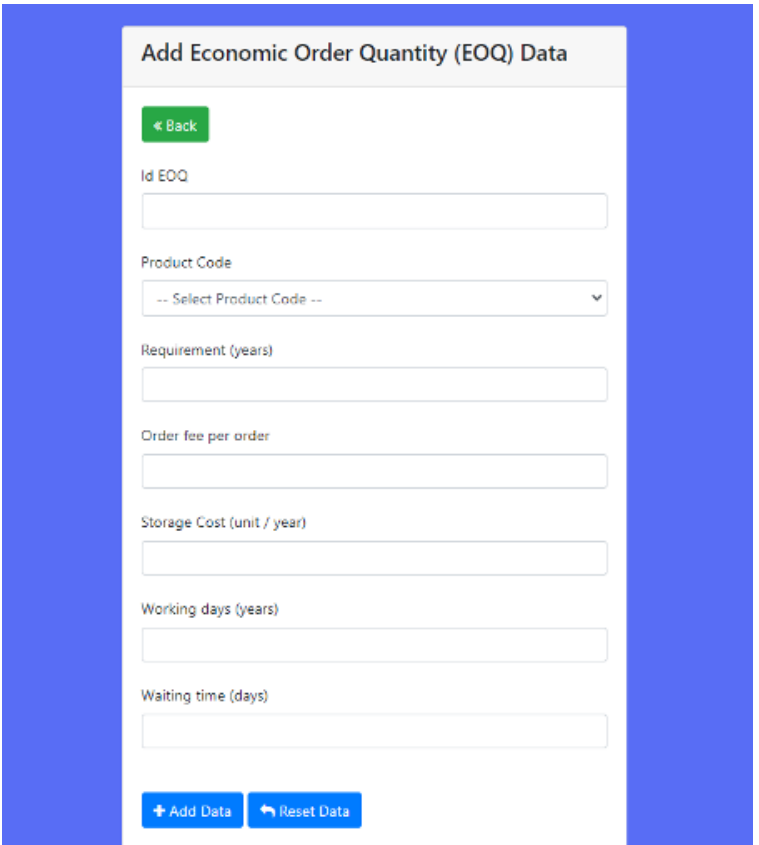

Figure 5. EOQ Data Browse Design

\section{Construction (Code $\&$ Test)}

a. Economic Order Quantity Algorithm Design The following algorithm is written for an inventory information system application.

BEGIN

NUMBER $r, s, p, 1$

INPUT $r$

INPUT $\mathrm{s}$

INPUT $p$

INPUT 1

INPUT hpt

$\sqrt{ }\left(2^{*} r^{*} \mathrm{~S}\right) / \mathrm{p} \rightarrow$ eog

$\left(p^{*}\right.$ eog $\left./ 2\right)+\left(r^{*} s^{*}\right.$ eog $) \rightarrow$ tc

$\mathrm{s} / \mathrm{eoq} \rightarrow \mathrm{frq}$

hpt/frq $\rightarrow$ dh eoq

$l * \mathrm{~d} / \mathrm{hpt} \rightarrow \mathrm{rop}$

OUTPUT eoq

OUTPUT tc

OUTPUT frg

OUTPUT dh_eog

OUTPUT rop

END

b. Economic Order Quantity Function

The following functions will be used in the inventory information system. 
using devices that are not limited to PCs, can also be tablets, smartphones, laptops. When accessing it with a web browser.

\section{b. Feedback}

Feedback in table 2, in the form of a user acceptance test, is information on the results of the end user's reaction to the inventory application, someone's performance on an assignment, etc. which is used as a basis for improvement.

Tabel 2. User Acceptance Test

\begin{tabular}{clc}
\hline No & \multicolumn{1}{c}{ A list of questions } & Percentage \\
\hline 1 & $\begin{array}{l}\text { Is the EOQ data management dashboard } \\
\text { easy to operate }\end{array}$ & $91 \%$ \\
\hline 2 & $\begin{array}{l}\text { Is EOQ data input understandable and } \\
\text { easy to use? }\end{array}$ & $93 \%$ \\
\hline 3 & $\begin{array}{l}\text { Is change EOQ data understandable and } \\
\text { easy to use }\end{array}$ & $93 \%$ \\
\hline 4 & $\begin{array}{l}\text { Does appear data EOQ understands and } \\
\text { is easy to use }\end{array}$ & $95 \%$ \\
\hline 5 & \begin{tabular}{l} 
Is the calculation process as expected? \\
\hline 6
\end{tabular} & $\begin{array}{l}\text { Is the process of accessing this inventory } \\
\text { application fast? }\end{array}$ \\
\hline 7 & $\begin{array}{l}\text { Is the data access process in this } \\
\text { inventory application fast? }\end{array}$ & $92 \%$ \\
\hline 8 & Is this inventory application sufficient? & $92 \%$ \\
\hline
\end{tabular}

Table 2, is the stage for testing user acceptance of, in general, users who test the inventory information system accept this application.

\section{CONCLUSION}

In general, this inventory information system can help users implement the company's existing inventory of incoming and outgoing goods. The application of the EOQ method can determine the volume and frequency of material orders needed to meet production needs and reduce the cost of each order.

\section{REFERENCES}

Anwar, R. S., Mikhratunnisa, \& Cahyono, T. D. (2019). Perancangan Aplikasi Berbasis Android Dengan Metode Economic Order Quantity Di Pt. Samawa Tirta Alam Sumbawa. Jurnal Tambora, 3(2), 49-59. Retrieved from http://www.jurnal.uts.ac.id/index.php/Tamb ora/article/view/289

Apriani, D., Aisyah, E. S., \& Anggraini, L. (2019). Rancang Bangun Sistem Informasi Inventory Peralatan Komputer Berbasis Website Pada
PT Indonesia Toray Synthetics. Technomedia Journal, 4(1), 15-29. https://doi.org/10.33050/tmj.v4i1.997

Atikah, A. (2017). Analisa dan Perancangan Sistem Informasi Pengadaan Bahan Baku Pada PT.XYZ. STRING (Satuan Tulisan Riset Dan Inovasi Teknologi), 1(2), 109. https://doi.org/10.30998/string.v1i2.1030

Cahyana, N. H., Yuwono, B., \& Asmoro, A. Y. (2012). Pengembangan Sistem Informasi Persediaan Barang Berbasis Web Di Pt . Putera Agung Setia. Pengembangan Sistem Informasi Persediaan Barang Berbasis Web Di Pt. Putera Agung Setia, 9(semnasIF), 252-258. Yogjakarta: UPN "Veteran" Yogyakarta. Retrieved from http://103-23-20161.isi.cloud.id/index.php/semnasif/article/ view/1106

Fatmawati, F., \& Munajat, J. (2018). Implementasi Model Waterfall Pada Sistem Informasi Persediaan Barang Berbasis Web (Studi Kasus: PT.Pamindo Tiga T). Jurnal Media Informatika Budidarma, 2(2), 1-9. https://doi.org/10.30865/mib.v2i2.559

Humaeni, A., Muanas, M., \& Sudradjat, S. (2019). Peranan Program Yongjin Erp Sebagai Sistem Informasi Akuntansi Pengendalian Persediaan Bahan Baku. Jurnal Ilmiah Akuntansi Kesatuan, $7\left(1^{\prime}\right)$, 213-218. https://doi.org/10.37641/JIAKES.V7I1'.201

Mujiastuti, R., Meilina, P., \& Rully, M. A. (2018). Implementasi Metode Economic Order Quantity (EOQ) pada Sistem Informasi Produksi Kopi. Jurnal Sistem Informasi, Teknologi Informatika Dan Komputer, 8(2), 119-126. Retrieved from https://jurnal.umj.ac.id/index.php/justit/article/download/.../2376

Nasution, A., \& Indriya, C. (2020). Pembelian Bahan Baku Optimal Ready Mix Concrete dengan Metode Economic Order Quantity. Jurnal Sistem Teknik Industri, 22(2), 25-32. https://doi.org/10.32734/jsti.v22i2.3827

Pressman, R. S., \& Maxim, B. R. (2015). Software Engineering: A Practitioner's Approach. In McGraw-Hill Education (Eighth, Vol. 8). New York City: McGraw-Hill Education.

Pudjiarti, E., Puspitasari, E., \& Septyawati, A. A. (2019). Sistem Informasi Persediaan Barang Berbasis Dekstop Pada Pt. Ultra Sakti. Jusikom : Jurnal Sistem Komputer Musirawas, $4(02)$,

111-119. https://doi.org/10.32767/jusikom.v4i2.584

Ramdhany, T., \& Fitriasih, N. (2019). Aplikasi Persediaan Barang Jadi Pada Pt Refika 
Aditama Bandung. In Jurnal Lpkia (Vol. 12). Retrieved from http://jurnal.lpkia.ac.id/index.php/jkb/articl e/view/230

Setiyanto, R., Nurmaesah, N., \& Rahayu, N. S. A. (2019). Perancangan Sistem Informasi Persediaan Barang Studi Kasus di Vahncollections. Jurnal Sisfotek Global, 9(1), 137-142. https://doi.org/10.38101/SISFOTEK.V9I1.26 7

Sidik, A., Waluyo, E. T. B., \& Susilawati, S. (2018). Perancangan Sistem Informasi Laporan Persediaan Barang Jadi PT Duta Prima Plasindo. Jurnal Sisfotek Global, 8(1), 7-12. Retrieved

from https://journal.stmikglobal.ac.id/index.php/s isfotek/article/view/161

Tarsono, 0., \& Khotimah, S. (2018). Peranan Economic Order Quantity dalam peningkatan Efisiensi pengelolaan persediaan pada PT. Martina Berto Tbk. Jurnal STEI Ekonomi, 26(2), 217-229. https://doi.org/10.36406/jemi.v26i2.225

Zahirah, S. H., \& Arista, A. (2019). Pengendalian Persediaan Dengan Menggunakan Metode Economy Order Quantity pada Distributor Makanan. Computer and Science Industrial Engineering (COMASIE), 11(01), 32-41. Retrieved from https://ejournal.itn.ac.id/index.php/valtech/ article/view/209 